University of Nebraska - Lincoln

DigitalCommons@University of Nebraska - Lincoln

USDA Forest Service / UNL Faculty Publications U.S. Department of Agriculture: Forest Service -National Agroforestry Center

2013

\title{
Turbidity and suspended-sediment changes from stream-crossing construction on a forest haul road in West Virginia, USA
}

Jingxin Wang

West Virginia University, jxwang@wvu.edu

Pamela J. Edwards

USDA Forest Service

Frederica Wood

USDA Forest Service

Follow this and additional works at: https://digitalcommons.unl.edu/usdafsfacpub

Wang, Jingxin; Edwards, Pamela J.; and Wood, Frederica, "Turbidity and suspended-sediment changes from stream-crossing construction on a forest haul road in West Virginia, USA" (2013). USDA Forest Service / UNL Faculty Publications. 247.

https://digitalcommons.unl.edu/usdafsfacpub/247

This Article is brought to you for free and open access by the U.S. Department of Agriculture: Forest Service -National Agroforestry Center at DigitalCommons@University of Nebraska - Lincoln. It has been accepted for inclusion in USDA Forest Service / UNL Faculty Publications by an authorized administrator of DigitalCommons@University of Nebraska - Lincoln. 


\title{
Turbidity and suspended-sediment changes from stream-crossing construction on a forest haul road in West Virginia, USA
}

\author{
Jingxin Wang ${ }^{\mathrm{a} \star}$, Pamela J. Edwards ${ }^{\mathrm{b}}$, and Frederica Wood ${ }^{\mathrm{b}}$ \\ ${ }^{a}$ Division of Forestry and Natural Resources, West Virginia University; ${ }^{b}$ USDA Forest Service, Northern Research Station, Parsons, \\ West Virginia
}

(Received 3 April 2012; final version accepted 3 December 2012)

\begin{abstract}
A forested headwater watershed in West Virginia was monitored to examine changes to in-stream turbidity following the construction of a $0.92 \mathrm{~km}(0.57 \mathrm{mi})$ haul road. Due to the design of the study, most of the sediment that entered the stream following road construction was known to result from the stream crossings and approaches to the crossings. Stream-water samples collected daily and sequentially during stormflow from 1999 through 2005 were used to interpret the effects of stream-crossing construction on turbidity and suspended-sediment concentrations (SSC). Daily and stormflow turbidity and SSC values increased as a result of the construction. Average sediment loads ( $\mathrm{kg}$ per storm) and total annualized sediment loads (kg per year) also increased significantly, both by a factor of about 1.8. Sediment delivery to the stream was caused by mechanical introduction of soil during stream-crossing culvert installation and fill-slope construction in the crossing approaches, and by erosion of those areas due to delays in vegetation re-establishment. Inputs from stream-crossing construction affected the overall sediment regime of the stream; the turbidity-discharge hysteresis changed from the normal clockwise pattern to a counter-clockwise pattern for about seven months. As the crossing fills and approach fill slopes became re-vegetated, they stabilized, and annualized sediment loads declined. However, at the end of the study, sediment exports remained above pre-disturbance levels.
\end{abstract}

Keywords: turbidity; water quality; forest road construction; fill slopes; hysteresis

\section{Introduction}

Road construction and use are the primary sources of sediment production during forest harvesting operations (Hornbeck \& Reinhart 1964). Unpaved roads accelerate erosion, affect run-off, and increase effective channel lengths in headwater catchments (Reinhart 1964; Binkley \& Brown 1993; Jones \& Grant 1996; MacDonald \& Coe 2008; Wemple et al. 1996). For example, one year after road construction in north central West Virginia, maximum turbidity in a roaded watershed exceeded maximum reference watershed turbidity by 3700 Jackson turbidity units (Hornbeck \& Reinhart 1964). Turbidity increases were attributed primarily to the lack of best management practices, resulting in poorly located skid roads and the dragging of cut timber in the stream channels (Kochenderfer \& Hornbeck 1999).

Road interception of precipitation and subsurface flow also can accelerate the transfer of hillside water to stream channels (Reinhart 1964; Wemple et al. 1996). In turn, watershed hydrology for both stormflow and baseflow can change, and sediment supplies to streams can increase, which can result in decreases in channel storage and stability and in direct and indirect effects to aquatic organisms (Hornbeck \& Reinhart 1964; Cornish 2001; Wemple et al. 1996; Dent et al. 2003; Madej \& Ozaki 1996; Eaglin \& Hubert 1993; Harr \& Nichols 1993). As a result of the direct changes that can occur, hydrologically connected road sections are considered channel extensions. Wemple et al. (1996) found that channel lengths increased up to $40 \%$ due to these linkages between roads and streams. In western Washington and Oregon, 88\% of road run-off emptied into ephemeral or intermittent streams (Bilby et al. 1989), which was similar to the $75 \%$ of road runoff that reached a stream channel in the Olympic Mountains of Washington (Reid \& Dunne 1984). A more extensive survey in

Corresponding author. Jingxin Wang, Division of Forestry and Natural Resources, 322 Percival Hall, West Virginia University, Morgantown, WV 26506 USA. Email: jxwang@wvu.edu

${ }^{\star}$ Member of the Forest Products Society. 
Washington on generally flat terrain found that $12 \%$ of roads on private timberlands were hydrologically connected (Martin 2009).

The largest increases of in-stream suspended sediment and turbidity occur during and immediately after road construction (Hornbeck \& Reinhart 1964; Swift 1988); however, road maintenance also can significantly increase erosion and sediment transport (Luce \& Black 2001). During and one year following construction, a more than five-fold increase of in-stream suspended sediment and turbidity has been reported (Hornbeck \& Reinhart 1964; Fredriksen 1970; Megahan \& Kidd 1972); but decreases in both parameters occur fairly quickly (Rice \& Wallis 1962; Hornbeck \& Reinhart 1964; Megahan \& Kidd 1972). Recovery often follows exponential declines in turbidity and suspended sediment, but elevated turbidity and sediment exports may persist for years (Hornbeck \& Reinhart 1964).

Stream crossings and their approaches are the portions of any road that are most intimately tied to streams and have the greatest potential to deliver pollutants to streams (Weaver \& Hagans 2004).
However, studies involving road construction, such as those described in the previous paragraphs, include sediment contributions from potentially the entire road length, with no ability to separate general road contributions from contributions at crossings. In this study, contributions to the stream from the road during and following construction were restricted to the stream crossings and short sections of their approaches, with the aim of isolating the effects of the crossings.

\section{Materials and methods}

\section{Study background}

The results described in this paper are part of a larger study primarily aimed at quantifying sediment delivery to a headwater channel in a managed watershed. Toward this end, silt fence was installed to line the entire stream network in a 32.7 ha watershed (Figure 1), which effectively eliminated hillside contributions of sediment. To avoid soil disturbance and create a sampling surface, the silt fence was not installed in a trench; instead, 20 to $25 \mathrm{~cm}$ of the bottom of the fence was turf-stapled to the

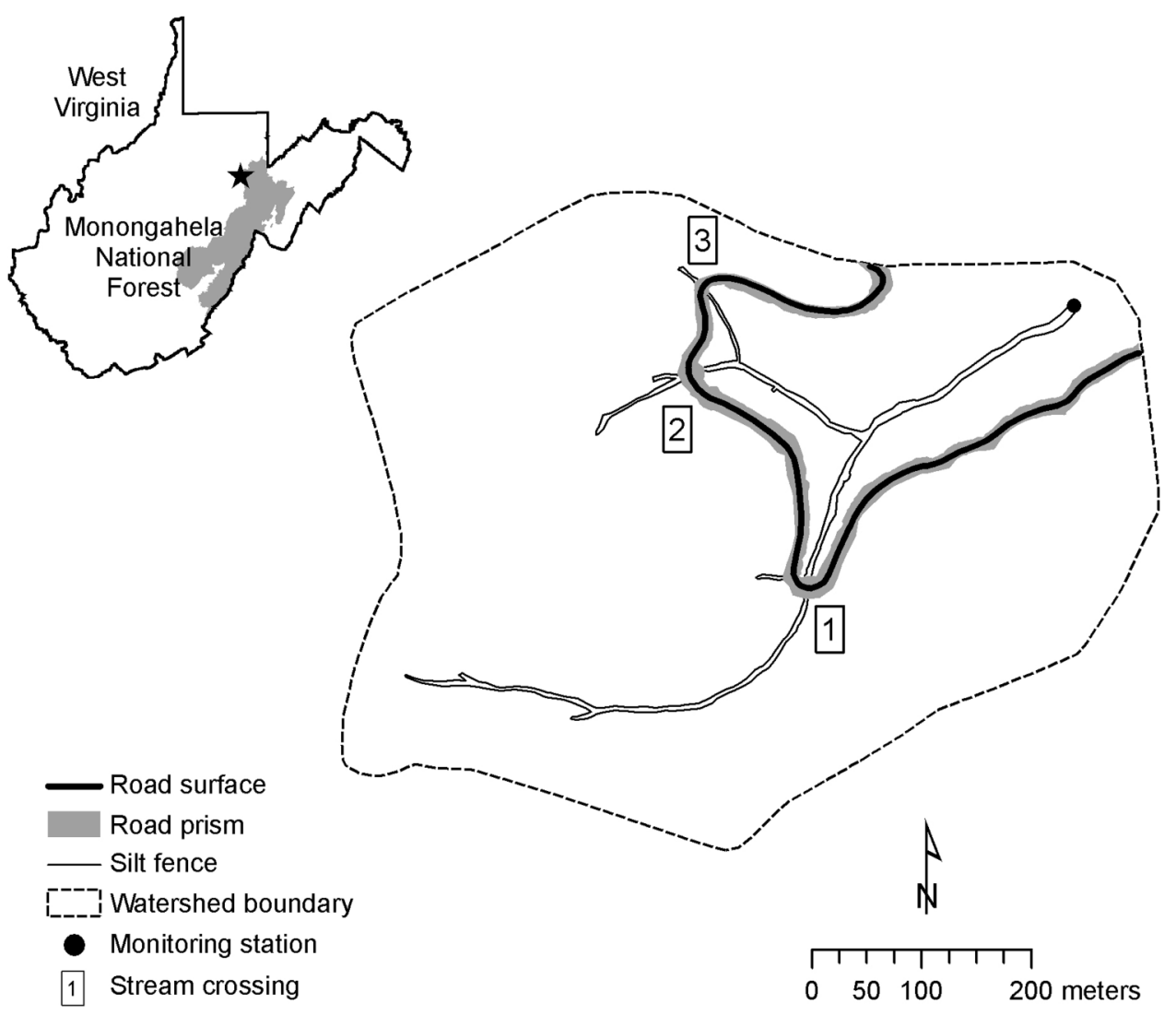

Figure 1. Location of the study watershed in the Monongahela National Forest, West Virginia, and schematic showing the road location and the stream, which is lined with silt fence. 
ground to sample hillside sediment delivery (Stedman 2008). The channel length for this watershed, including the ephemeral headwater reaches, is $1265 \mathrm{~m}$. Stream width near the mouth of the watershed is $4.2 \mathrm{~m}$.

During the period of road construction, sections of the silt fence in the three stream crossings and the approaches to the crossings were rendered temporarily ineffective at keeping sediment out of the stream channel (as described later). Prior to road construction, turbidity and suspended-sediment concentrations were measured to determine in-stream contributions of sediment for comparison to hillside contributions. Once road construction began and the silt fence in the areas around the stream crossings was ineffective, the objectives of in-stream monitoring shifted to examine sediment additions from the stream crossings to the channel.

Haul-road construction began in the treatment watershed on 8 July 2002. The road was a cut-andfill type, with three corrugated-steel pipe culvert stream crossings (Figure 1). A few days before road construction began, the silt fence in the proposed crossing areas was cut and removed. However, the road construction contractors detached an additional length of the upstream and downstream sections of the silt fence on both sides of the stream at each crossing just before construction of each crossing began; they did this because they were concerned about damaging or covering the silt fence in the crossing approaches during fill-slope construction. Consequently, soil could reach the stream within the lengths of the fill-slope approaches where the silt fence had been removed. In addition, during road construction, soil was mechanically pushed downslope to create the fill slope. A substantial portion of the excess soil at the crossing approaches overtopped or knocked down the silt fence, contributing additional sediment to the stream channel. Until the silt fence was reconstructed, the additional sediment reached the channel by water-driven and gravity-driven erosion.

The contractors built check dams below the first and third stream crossings during the installation of the culverts. The dams consisted of two to three layers of straw bales staked in place across the entire stream width. Based on estimates of sediment stored behind the check dams before they were removed in fall 2003, several tons were estimated to have reached the channel from those associated stream crossings and approaches (USDA Forest Service, unpublished data). The silt fence was reconstructed parallel to the channel at the first stream crossing on 1-2 October 2002 and at the second and third stream crossings on 10 April 2003. Silt fence was
Table 1. Culvert size and fill characteristics for the three stream crossings.

\begin{tabular}{lcc}
\hline \multirow{2}{*}{$\begin{array}{l}\text { Culvert } \\
\text { diameter }\end{array}$} & \multicolumn{2}{c}{ Vertical distance $(\mathrm{m})$} \\
$\mathrm{n})$ & from road surface to top of culvert \\
\cline { 2 - 3 } 1.52 & Upstream & Downstream \\
1.22 & 4.0 & 7.4 \\
0.91 & 3.7 & 7.9 \\
& 2.0 & 4.5 \\
\hline
\end{tabular}

never installed across the upstream or downstream faces of the crossings, so the crossings remained the primary sources of hillside sediment to the stream after silt-fence reconstruction.

The $0.92 \mathrm{~km}$ road was roughed in during 2002, but it was not completed until late summer 2003. Initially, the stream crossings were completed only to the degree needed to allow equipment to access the next road segment under construction. From 23 to 25 July 2002, a pair of undersized temporary culverts were placed side by side at the first stream crossing and partially backfilled to allow heavyequipment movement. These culverts were removed on 4 September 2002 and replaced with a single, larger-diameter permanent culvert. Permanent culverts were installed in the second and third stream crossings as road construction reached each crossing (9-10 September 2002 and 12-13 September 2002, respectively). Culvert sizes and their fill characteristics are described in Table 1.

The fills over the three stream crossings and fill slopes in the approaches remained unvegetated over the winter of 2002-2003. The crossings and approaches were hydro-seeded on 7 May 2003, followed by an application of chopped mulch. Reasonably thick grass and herbaceous vegetation became established quickly. In late summer 2003, the road was surfaced with limestone gravel to an average depth of $15 \mathrm{~cm}$; approximately $30 \mathrm{~cm}$ of gravel was applied at the stream crossings.

\section{Streamflow Measurements and water sampling}

A co-located streamflow gauging and stream water sampling station was constructed near the outlet of the watershed (Figure 1) in fall 1999. To aid in data interpretation, precipitation measured at a weather station $6.4 \mathrm{~km}$ from the study watershed using a 20.3 $\mathrm{cm}$ standard rain gauge and a Belfort weighing-type recording rain gauge also was used for this study.

Streamflow was measured using an American Sigma 950 flow meter with an area-velocity probe attached to the bed of the stream, which was 
composed of exposed bedrock. The American Sigma probe recorded velocity and stage every five minutes, but velocity measurements were found to be inaccurate: their readings drifted. By contrast, the stage readings were quite stable and accurate, based on regular checks and calibrations of stage. Consequently, the stage readings were used in the calculation of streamflow. For the few times when the probes malfunctioned and stage measurements were not available, a prediction equation was used to estimate stage for the study watershed $(y)$ from stage readings from two nearby watersheds gauged with $90^{\circ} \mathrm{V}$-notch weirs $(x)$. The $R^{2}$ value for the prediction equation was 0.67 .

Streamflow $\left(\mathrm{m}^{3} / \mathrm{s}\right)$ was determined using the slug (salt) dilution gauging method (Day 1976, 1977) through the range of flows that extended from very low baseflows to near bankfull. The stage present during each salt dilution test also was recorded. The streamflow $(y)$ and stage $(x)$ data pairs determined from the salt dilution tests were graphed, which showed there was a break in the apparent regression relationship at stage $=4.2 \mathrm{in}$. Consequently, separate regression curves were fitted to the two portions of data using TableCurve 2D software. The regression curve $R^{2}$ value was 0.97 for stages $\leq 4.2$ in and 0.99 for stages $>4.2 \mathrm{in}$. The five-minute stage measurements collected with the American Sigma probe then were applied to the regression equation to calculate streamflow.

Water samples for turbidity and suspended-sediment analyses were collected once daily using an American Sigma model 900 automatic pumping sampler. While most daily samples were collected during non-storm periods, the timing of some daily samples did coincide with storm events. However, additional samples were collected throughout storm events with an ISCO model 2700 automatic sampler. The ISCO sampler was actuated using precipitation rather than stage, and then sampled on pre-set time intervals ( 30 or 60 minutes) to obtain a thorough representation of turbidity and suspended sediment behavior during storms (Edwards and Owens 1995).

The area in the channel from which water samples were extracted by the automatic samplers was also located on exposed bedrock. The bedrock did not promote sediment deposition, so the sampler did not pick up sediment from the stream bottom, and erroneous, elevated sediment levels in samples were avoided. Instead, turbidity and suspended-sediment concentrations measured in the watershed were those actually present in the water column.

Water sampling began on 2 November 1999 and continued through 7 July 2002. At that time, haul- road construction began, so sampling was suspended due to the danger to personnel and equipment from tree felling and fill-slope construction. Storm sampling restarted on 15 October 2002 and daily sampling resumed on 29 May 2003. Sampling continued through 30 September 2005. The pre-treatment period includes the time prior to haul-road construction (1999 to June 2002). The post-treatment period extends from the restart of sampling in October 2002 to September 2005, even though construction was ongoing during that period (July 2002 to September 2003). However, by the re-initiation of sampling in October 2002, all of the crossings were in place, though not constructed to final standards.

\section{Laboratory analyses}

Both suspended-sediment concentration (SSC) and turbidity were examined in this study. SSC is important because it provides a direct measurement of the amount of inorganic sediment present in the water column at the time of collection. Turbidity is a measure of water clarity and is affected by fine sediment, organic matter, and microorganisms, and water color due to changes in light scattering or absorption. While it is only an indirect measure of SSC (MacDonald et al. 1991), turbidity is an important water-quality parameter because turbid water is the most obvious visible evidence of elevated sediment in a water body, and many water-quality regulations are described in terms of turbidity levels due to its visibility and relative ease of determination.

All water-sample analyses were performed at the USDA Forest Service's Timber and Watershed Laboratory in Parsons, West Virginia. Turbidity was determined using a Hach model 18900 ratio turbidimeter, which was calibrated in NTU using formazin standards (Edwards et al. 2009). Suspended-sediment concentrations $(\mathrm{mg} / \mathrm{L})$ were determined using US EPA method 160.2. This method involves sample filtration and drying and combusting the filters to obtain only the mineralsediment fraction associated with the water sample.

\section{Calculations and statistical analyses}

Statistical analyses compare turbidity and SSC values during pre-treatment to those during posttreatment for daily and stormflow samples. For daily turbidity, daily SSC, and storm turbidity, the measured values are used in the statistical analyses. For SSC during storms, each SSC measurement was flow-weighted and a flow-weighted mean concentration calculated for each storm; those per-storm flowweighted mean concentrations then were used in the 
statistical comparisons of pre-treatment and posttreatment. Flow-weighted concentrations better reflect the entire range of concentrations present during stormflows.

Sediment exports or loads $(\mathrm{kg})$ were calculated for each storm sample by determining the total discharge occurring from the last sample to the current sample and applying that flow to the current sample. For the first sample in each storm, the instantaneous discharge at the time the sample was taken was used in the calculation. The means of these per-storm loads were compared statistically between pre-treatment and post-treatment periods. The pre-treatment and post-treatment periods were not equal in length, so to compare total storm loads between the periods, per-storm loads were summed and then expressed on an annualized basis $(\mathrm{kg} / \mathrm{y})$. This was also done to compare exports during pre-treatment, construction, and each of the first two years following construction. Similarly, to compare this study to other studies, the annualized exports also were converted to an annualized unit-area basis $\left(\mathrm{kg} \mathrm{ha}^{-1} \mathrm{y}^{-1}\right)$. Sediment exports were not calculated for daily samples, so the annualized exports do not include this portion of the watershed loads. However, since daily samples were associated primarily with baseflow periods during which there is very little associated sediment transport, this exclusion is not expected to affect the interpretation of the results substantially.

Nonparametric methods were used for statistical comparisons of treatment periods because the data were not normally distributed. Wilcoxon two-sample tests and mean scores were used to transform the data to an ordinal scale to test for differences. Statistical comparisons were made using Statistical Analysis Systems software (SAS Institute 2004).

In addition to the statistical comparisons, turbidity increases post-treatment were examined to determine whether it was likely that sediment contributed from stream-crossing construction would have resulted in turbidity levels violating West Virginia's water-quality standards (West Virginia Division of Forestry 2009). In West Virginia, water-quality standards for sediment are based on changes in turbidity compared to background levels. These standards allow turbidity increases by point or non-point sources of no more than 10 nephelometric turbidity units (NTU) above background levels for waters with background levels of $\leq 50 \mathrm{NTU}$, or no more than a $10 \%$ increase plus the 10 NTU minimum for waters with background levels $>50$ NTU. Background levels of turbidity are defined in these standards as those occurring at the time of sampling directly upstream from where sediment discharge into the water body is occurring.
Since we did not sample directly above and below the stream crossings, we have used the mean turbidity of the entire pre-treatment period as a single-value surrogate for the background level against which the daily post-treatment samples are compared. Thus, the difference between each measured post-treatment value and the pre-treatment mean was used to determine the magnitude of change. While there is some potential error in the interpretation of individual samples using this approach, it is nonetheless deemed reasonable because the pretreatment data-set was relatively long and the variability in turbidity during that time was relatively small (as described later).

A similar approach using the difference between background turbidity and maximum turbidity levels is more tenuous, and therefore is not attempted for stormflow. Since turbidity normally increases during storm events even in undisturbed watersheds, simply taking the difference between each background (e.g. pre-storm) and maximum turbidity levels within a storm will not reflect the increase solely due to the treatment for that storm (i.e. that calculation does not account for the turbidity increase that would have occurred in the absence of treatment). Furthermore, every storm has its own unique sediment exports that are not easily predicted or estimated, so it is not possible to calculate background stormflow turbidity to estimate this additional part of the background calculation.

\section{Results and discussion \\ Daily samples}

Pre-treatment daily samples averaged 1.8 NTU, with a standard deviation of 6.0 NTU (Table 2). Only two samples $(0.3 \%)$ exceeded 25 NTU (61 and 147 NTU) during the pre-treatment period (Figure 2a). Following road construction, daily samples averaged 7.4 NTU, with a standard deviation of 11.6 NTU (Table 2). Sixteen samples (2.7\%) exceeded 25 NTU, seven $(1.2 \%)$ exceeded $50 \mathrm{NTU}$, and three $(0.5 \%)$ exceeded $100 \mathrm{NTU}$ (107, 111, and 123 NTU) (Figure 2a). Six of the samples with turbidities exceeding 25 NTU were collected during some portion of a storm event. Six of the seven samples with turbidity $>50$ NTU occurred in June and July 2003; this included the period in which construction was ongoing. Precipitation during those months totaled $41 \mathrm{~cm}$, with four events having precipitation $>3.1 \mathrm{~cm}$.

Daily post-treatment turbidities were significantly higher than in the pre-treatment period (Table 2), which suggests that the stream-crossing construction had an effect on water quality during discharges dominated by baseflow. For the entire 
Table 2. Descriptive statistics and nonparametric statistical comparisons of turbidity and suspended-sediment concentration (SSC) between treatment periods for daily samples.

\begin{tabular}{lcccrr}
\hline & \multirow{2}{*}{$\begin{array}{c}\text { Number of } \\
\text { Period }\end{array}$} & \multicolumn{2}{c}{ Turbidity (NTU) } & & \multicolumn{2}{c}{ SSC (mg/L) } \\
\cline { 2 - 5 } & samples & Mean & SD & Mean & SD \\
\hline Pre-treatment & 759 & $1.8^{\mathrm{a}}$ & $7.4^{\mathrm{b}}$ & 11.6 & 75.5 \\
Post-treatment & 594 & 7.0 & $23.8^{\mathrm{b}}$ & 105.1 \\
\hline
\end{tabular}

Note: Within columns, values followed by different superscript letters are significantly different $(\mathrm{p}<.05)$ based on Wilcoxon mean scores. NTU = nephelometric turbidity units.
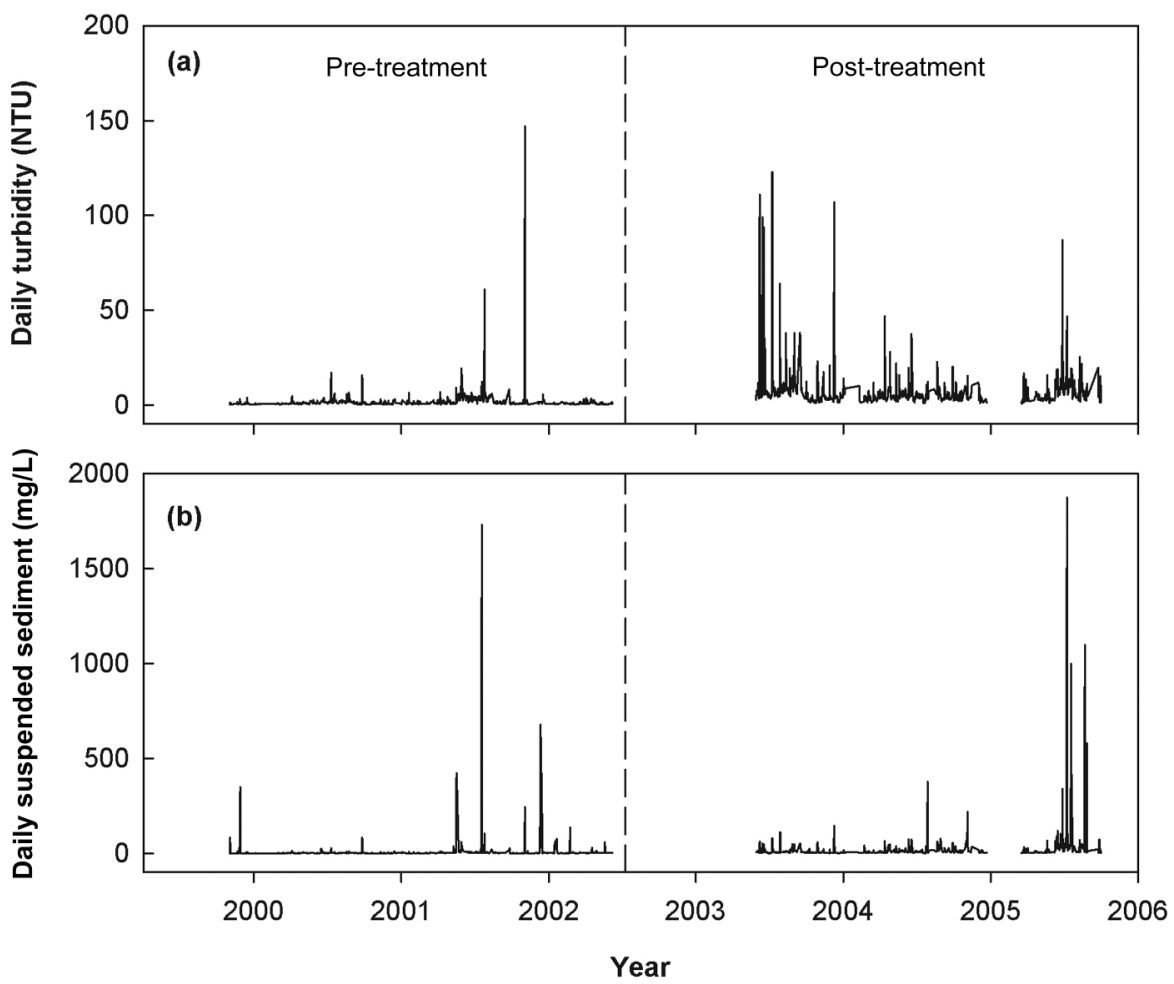

Figure 2. (a) Daily turbidity and (b) daily suspended sediment concentration during the pre-treatment and post-treatment periods. The vertical dashed line indicates the start of road construction in the watershed.

post-treatment period, the increase of means over pre-treatment was only 5.6 NTU (Table 2), so during most of the post-treatment period changes in water clarity probably would have been unnoticeable much of the time. Turbidity begins to become visible to the human eye at about 5 NTU (Strausberg 1983), and so during most non-storm periods these streams would have appeared clear or nearly clear.

These results are representative of what is typically reported for average values associated with baseflow or predominantly baseflow samples during road and stream-crossing construction in other locations. Lane and Sheridan (2002) monitored turbidity above and below a newly constructed stream crossing for five months in Australia. Mean baseflow turbidity increased from 1.7 NTU above the crossing to 3.7 NTU below the crossing. Fowler et al. (1988) measured turbidity during forest road construction in central Washington. They found slightly higher increases during the construction phase than our results, but their average turbidity remained relatively low. Mean turbidity in hourly samples increased from $<1 \mathrm{NTU}$ prior to construction to 24 NTU during construction and then averaged 1 NTU during each of the first two years after construction.

However, averages hide some of the information provided by individual data points. Figure 2a shows that the greatest increases in turbidity were concentrated in 2003, through 30 September, when road 
and crossing construction was ongoing. The average turbidity of daily samples in 2003 during construction was $12.8 \mathrm{NTU}$, more than $10 \mathrm{NTU}$ greater than the average daily pre-treatment turbidity value. During the entire post-treatment period, 70 days had samples with turbidity values that exceeded the pre-treatment background by more than 10 NTU; thus, based on the pre-treatment mean as a surrogate of background concentrations, all of those samples would have exceeded the maximum increase of 10 NTU allowed under West Virginia water-quality standards for streams with background turbidity values $\leq 50 \mathrm{NTU}$ and would have resulted in visible reductions in water clarity.

There was a second period, in 2005, during which turbidity increased markedly (Figure 2a), but the reason for this increase is unknown. It occurred during a period of frequent rain events, but actually came after the largest events of that year, with most of the precipitation events during that time being less than $20 \mathrm{~mm}$ (Figure 3c). There was some timber harvesting that occurred in the southeast portion of

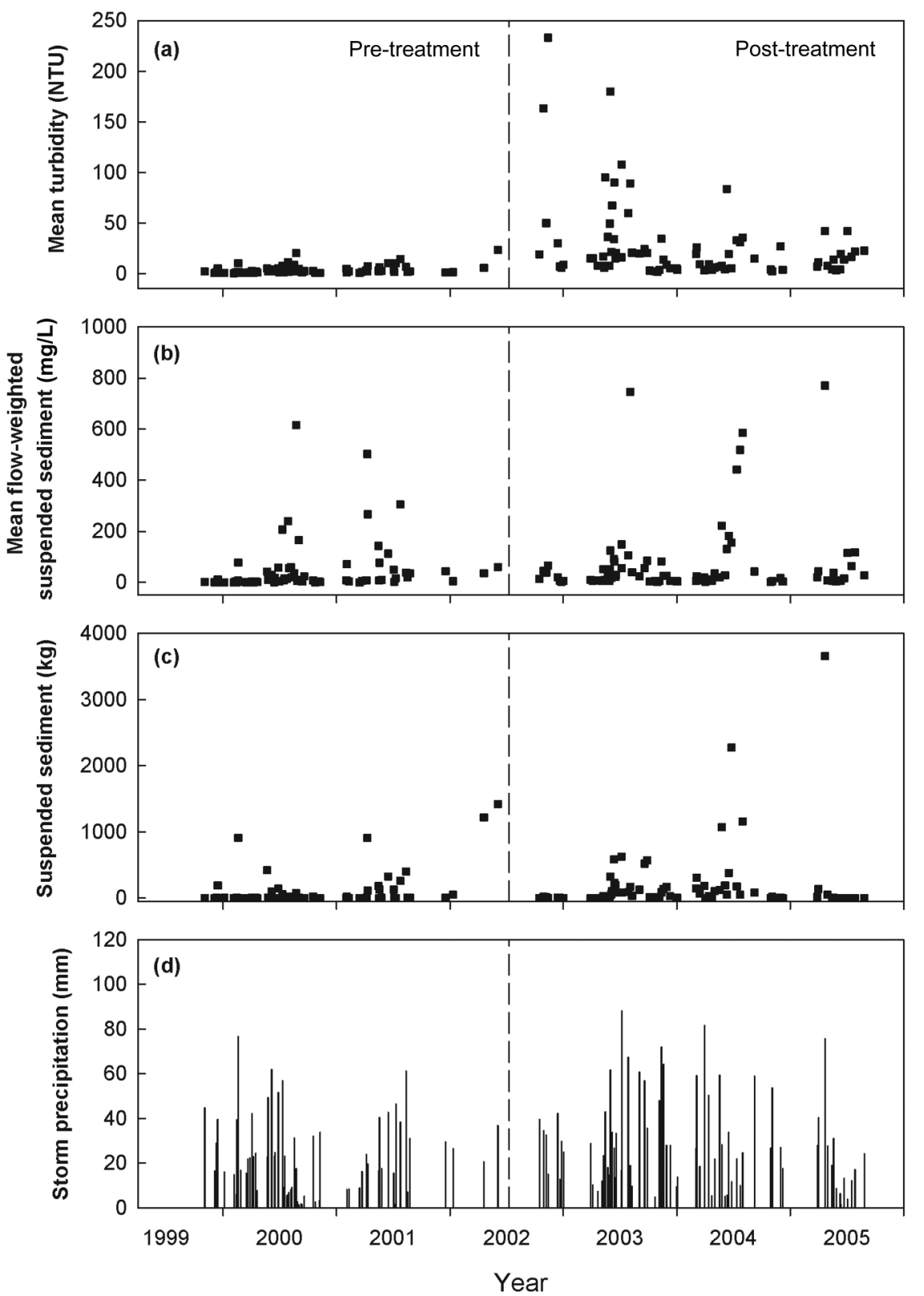

Figure 3. (a) Turbidity, (b) mean flow-weighted suspended-sediment concentration, (c) storm loads, and (d) precipitation totals for storms during the pre-treatment and post-treatment periods. The vertical dashed line indicates the start of road construction in the watershed. 
the watershed, including along the channel. Several trees upstream of the first stream crossing and within a few meters of the channel were uprooted by trees falling into them during felling (Stedman 2008). As a result, in that same area, about $30 \mathrm{~m}$ of the silt fence was knocked off its stakes and onto the ground for about two weeks. The exposed soil on the root wads from the uprooted trees faced the channel, and may have been the source of the sediment responsible for the turbidity increases.

Comparisons of daily SSC between pre-treatment and post-treatment periods also indicate increases as a result of stream-crossing construction (Table 2). However, changes to daily SSC seem to have occurred quite differently than for turbidity. From Figure $2 b$, the increase in mean SSC appears to have resulted from small but sustained increases in suspended sediment throughout much of the post-treatment period, and there was no cluster of more-elevated concentrations in 2003. Again, the exception is in 2005 when there were some very large increases in daily SSC; the cause of these is assumed to the same as the cause of the turbidity increases.

The post-treatment differences in turbidity and SSC characteristics provide some possible insight into how particle size availability changed through time. Together, turbidity and SSC suggest that the majority of particles initially (2003) present in daily samples during post-treatment were dominated by fine sediments (e.g. clays and silts) and then later by larger-size fines (e.g. small to medium-sized sands). As they initially were made available during crossing construction, fines were easily transported and retained in suspension by low-energy (i.e. daily) flows, thereby contributing to the elevated turbidity levels in 2003. Fines also have lower masses, and thus less influence on SSC, than larger particles (SSC is dependent upon total mass remaining after combustion of the filters that have captured suspended particles), so SSC did not increase to the degree that turbidity did in 2003 . As constructionderived fines became increasingly unavailable due to stream flushing and fill stabilization, a portion of small-to-medium-sized sands from construction remained and continued to be suspended in the water column by low-energy daily flows. The greater weights of sand could result in elevated SSC levels, but they would settle out rapidly during turbidity analyses and have little influence on those measurements.

\section{Stormflow samples}

Prior to crossing construction, average stormflow turbidity was not much greater than the average daily turbidity (Tables 3 and 2, respectively), but the influences of road and crossing construction on turbidity were greater for stormflow samples. Mean storm turbidity increased significantly, by almost eight times (3.6 to $28.3 \mathrm{NTU}$ ), from pretreatment to post-treatment (Table 3). Most of the largest increases in turbidity were associated with storms that occurred during the road-construction period in mid-2003, prior to road completion and application of seed, mulch, and gravel (Figure 3a).

Other studies have also reported changes in turbidity, from new crossing construction or the use of existing crossings, very similar to those found for this study. Mean turbidity measured during storm events above and below a newly constructed stream crossing in Australia increased from 3.8 NTU above the crossing to 15.6 NTU below the crossing (Lane \& Sheridan 2002). Dent et al. (2003) monitored turbidity at established crossings during storm events for two winters in Oregon. Mean turbidity was higher below the crossings by 12.5 NTU in year 1 and $9.8 \mathrm{NTU}$ in year 2 ; the increases were attributed to heavy truck traffic, shallower rock surfacing, and longer drainage ditches. Cornish (2001) measured storm turbidity from watersheds in Australia before and after road construction and harvesting. The watersheds with both treatments had mean turbidity increases, while the logging-only watersheds had mean turbidity decreases.

Table 3. Descriptive statistics and nonparametric statistical comparisons of turbidities and suspended-sediment concentration (SSC) between treatment periods for stormflow samples.

\begin{tabular}{lcrrr}
\hline Period & Number of samples & Parameter & Mean & \multicolumn{1}{c}{ SD } \\
\hline Pre-treatment & 72 & Turbidity (NTU) & $3.6^{\mathrm{a}}$ & 4.3 \\
& & SSC (mg/L) & $50.2^{\mathrm{A}}$ & 107.7 \\
Post-treatment & 79 & Turbidity (NTU) & $28.3^{\mathrm{b}}$ & 40.6 \\
& & SSC (mg/L) & $74.9^{\mathrm{B}}$ & 151.4 \\
\hline
\end{tabular}

Note: Within a parameter (turbidity or SSC, respectively), values followed by different superscript letters are significantly different $(\mathrm{p}<.05)$ based on Wilcoxon mean scores.

$\mathrm{NTU}=$ nephelometric turbidity units. 
Table 4. Descriptive statistics and nonparametric statistical comparisons of sediment loads within storms between periods. Annualized sediment loads are presented to account for differences in the lengths of the pre-treatment and post-treatment periods, and on an annualized unit-area basis for comparisons to other studies.

\begin{tabular}{lccccc}
\hline & & \multicolumn{3}{c}{ Sediment load } \\
\cline { 3 - 5 } Period & $\begin{array}{c}\text { Number of } \\
\text { samples }\end{array}$ & $\begin{array}{c}\text { Mean } \\
(\mathrm{kg} \text { per storm })\end{array}$ & $\begin{array}{c}\text { Annualized exports } \\
(\mathrm{kg} / \mathrm{y})\end{array}$ & $\begin{array}{c}\text { Annualized unit-area exports } \\
\left(\mathrm{kg} \mathrm{ha}^{-1} \mathrm{y}^{-1}\right)\end{array}$ \\
\hline Pre-treatment & 72 & $101^{\mathrm{a}}$ & 268 & 2786 & 85 \\
Post-treatment & 79 & $186^{\mathrm{b}}$ & 512 & 4972 & 152 \\
\hline
\end{tabular}

Note: Values followed by different superscript letters are significantly different $(p<.05)$ based on Wilcoxon mean scores.

Unlike the daily results, there were no substantial increases in stormflow turbidity (Figure 3a) or SSC (Figure 3b) during 2005. This was surprising, given the magnitude of the increases for both that were observed in 2005 during daily flows. A possible reason for the differences between daily and stormflow results is that there was sufficient sediment reaching or available in the channel (e.g. from the uprooted trees resulting from harvesting) that the influence of those inputs was measurable during baseflows (since dilution was low), but not during stormflows (when the inputs were diluted by increased flows).

Mean flow-weighted SSC increased by about $50 \%$ from pre-treatment to post-treatment (Table 3). These concentration increases also contributed to a significant post-treatment increase in average per-storm sediment exports (Table 4). The storm loads and annualized loads both increased by about 1.8 times (Table 4). On an annualized area basis $\left(\mathrm{kg} \mathrm{ha}^{-1} \mathrm{y}^{-1}\right)$, the exports from this watershed (Table 4) tended to be greater than some other forested watersheds in this area. Kochenderfer and Hornbeck (1999) reported values for a watershed in north central West Virginia in which $4.5 \%$ of the catchment was made up of haul roads that underwent logging. Sediment yields were not reported for the pre-disturbance period, but during logging the sediment yield was $123 \mathrm{~kg} \mathrm{ha}^{-1} \mathrm{y}^{-1}$, which declined to 77 and $58 \mathrm{~kg} \mathrm{ha}^{-1} \mathrm{y}^{-1}$ during the first and second years, respectively, following the termination of logging. Edwards et al. (2004) reported fairly small exports (approximately 20 to $26 \mathrm{~kg} \mathrm{ha}^{-1} \mathrm{y}^{-1}$ ) from an unharvested watershed in northern West Virginia during years that did not experience flood events. By comparison, during those same years, an adjacent harvested watershed that had the equivalent of about $10 \%$ of the watershed area in roads had exports between 45 and $59 \mathrm{~kg} \mathrm{ha}^{-1} \mathrm{y}^{-1}$. The approximate doubling of sediment loads is analogous to what we observed, but the pre-treatment period loads here were about four times as high as those reported by Edwards et al. (2004), suggesting that other watershed differences exist. Some of these other differences may be due to natural conditions, such as soil erodibility, but some also may be due to watershed land use histories (Kochenderfer et al. 1987).

In the studies by Edwards et al. (2004) \& Kochenderfer \& Hornbeck (1999), attention was paid to implementing best management practices (BMPs) as quickly as possible. In the latter study, the road system had only two stream crossings, which were in the upper headwaters where the stream was much smaller than the crossings in this study. In both studies, the roads were completed quickly and did not overwinter in uncompleted states as the road did in our study. In a watershed in West Virginia, where road BMPs were intentionally not employed and bulldozed skid roads made up $3.6 \%$ of the watershed (no haul roads were present) (Kochenderfer \& Hornbeck 1999), annual sediment losses were much greater during logging and skidding and in the following year than what we found. The respective values were 3226 and $323 \mathrm{~kg} \mathrm{ha}^{-1} \mathrm{y}^{-1}$. Forty-five percent of the bulldozed skid roads were within $25 \mathrm{ft}$ of the stream (Hornbeck \& Reinhart 1964), making them more direct conduits of sediment delivery. In some respects this is more similar to the crossing and stream connectivity found in our study, but it is unknown how much the total sediment exports would have been in the current study had sediment contributions from most of the length of the road system not been excluded from delivery to the stream system by silt fence.

While there were some individual mean flowweighted SSC and export values that were quite elevated during the post-treatment period (Figures $3 \mathrm{~b}$ and $3 \mathrm{c}$, respectively), overall similar numbers and magnitudes of SSC and export values were observed during pre-treatment (Figure 3b). Five of the six highest stormflow-weighted SSC means during post-treatment coincide with large precipitation events $(\geq 25 \mathrm{~mm})$, and four of the seven highest export values were associated with large storm events 

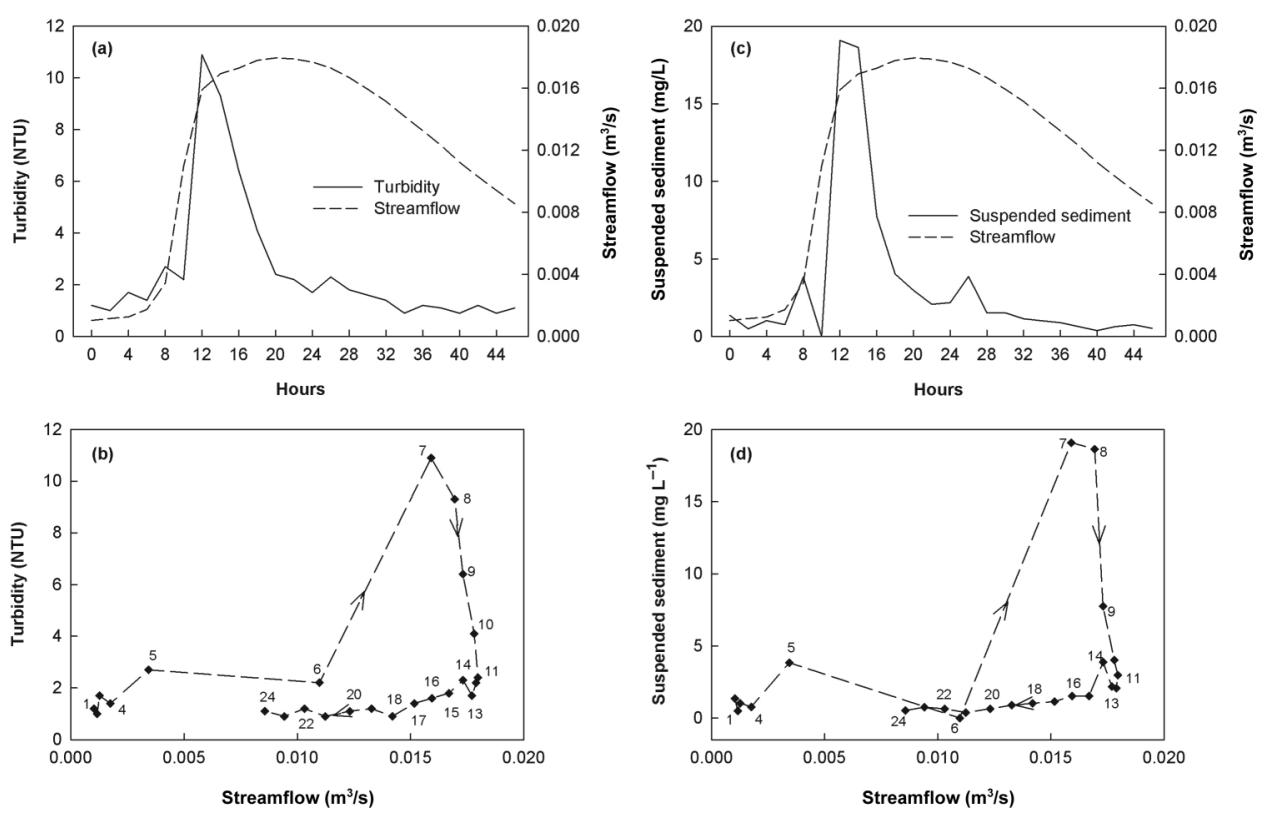

Figure 4. (a) Typical turbidity-discharge and (c) suspended sediment-discharge responses for a storm occurring on 3-5 April 2000, which is representative of behavior prior to watershed disturbance; (b) clockwise turbidity-discharge and (d) suspended sediment-discharge hysteresis for the storm. Numbers in (b) and (d) indicate the sample collection sequence.

(Figure 3c), but many other large precipitation events throughout the pre-treatment and post-treatment periods (Figure 3d) do not have particularly high SSC or exports associated with them (Figures $3 \mathrm{~b}$ and $3 \mathrm{c})$. Instead, the increases of within-storm SSC and exports observed during post-treatment seem to be due primarily to frequently occurring small increases associated with SSC $\leq 200 \mathrm{mg} / \mathrm{L}$ and exports $\leq 400 \mathrm{~kg}$. These findings are consistent with the low values of correlation coefficients for stormflow SSC values and storm precipitation totals and for per-storm loads and storm precipitation totals. For pre-treatment, post-treatment, and the entire study period the correlation coefficients are $0.04,0.00$, and 0.08 , respectively for SSC. These respective values increase somewhat for loads $(0.30,0.15$, and 0.25$)$, but they are still relatively poor.

This poor correlation does not mean that storms are not important for providing the mechanisms for dislodging and transporting sediment, because they are - e.g. compare mean daily and storm SSC values in Tables 2 and 3 - but the poor correlation does indicate that there are many other factors that also affect sediment exports. One very important variable, especially in forested watersheds, is the availability of sediment. While sediment availability was affected throughout the post-treatment period, turbidity-discharge and SSC-discharge relationships indicate that quantities of sediment large enough to substantially alter sediment routing were available for transport during part of the construction period.

Prior to watershed disturbance, turbidity-discharge (Figures 4a, 4b) and SSC-discharge (Figures 4c, 4d) responses were typical for headwater streams in central Appalachian forests (Stuart and Edwards 2006): both parameters generally increased quickly in response to increasing discharge, peaked prior to or near the time of peak discharge, and then receded to low levels more quickly than the hydrograph (Figures $4 \mathrm{a}, 4 \mathrm{c}$ ). This type of response is indicative of a watershed that has a limited supply of sediment available for transport (Williams 1989), also referred to as being supplydependent (Rice et al. 1979), and defined by clockwise hysteresis of the temporal turbidity-discharge and SSC-discharge relationships (Figures 4b, 4d). Beginning in April 2003 and extending through that autumn, turbidity and SSC typically peaked after discharge, and the hydrograph returned to baseflow conditions more rapidly than turbidity or SSC returned to pre-storm levels; that is, the turbidity or concentration lines are generally to the right of the streamflow line during the recession limb of the hydrograph (Figures 5a, 5c). These conditions resulted in counter-clockwise hysteresis (Fig. 5b, 5d). The lag between peak discharge and turbidity or SSC, and counter-clockwise hysteresis, indicate that the sediment sources that were controlling 

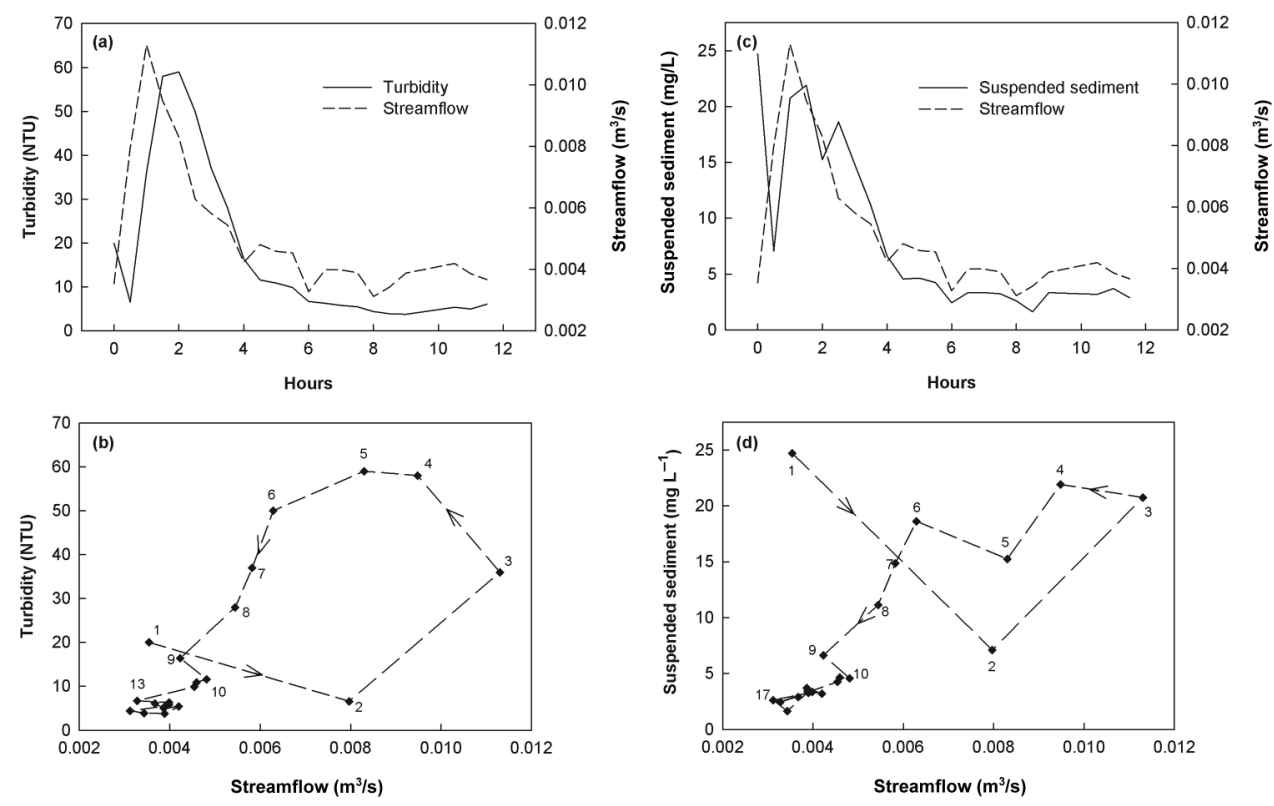

Figure 5. (a) Turbidity-discharge and (c) suspended sediment-discharge responses for a storm occurring on 15-16 May 2003, which is representative of behavior during about seven months when stream-crossing construction yielded large inputs of sediment to the stream (turbidity and suspended sediment peaked at about the time of or after peak flow when concentrated in-channel sediment sources were available); (b) counter-clockwise turbidity-discharge and (d) suspended sediment-discharge hysteresis for the storm. Numbers in (b) and (d) indicate the sample collection sequence.

sediment losses (i.e. turbidity and SSC) were from an upstream source (Asselman 1999; Bača 2002), or what is termed a stream-power-dependent system (Rice et al. 1979). In this watershed, the upstream sediment sources were the stream crossings and adjacent areas, in particular the sediment held within the check dams just downstream of the first and third stream crossings. The last storm for which counterclockwise hysteresis was observed occurred in October 2003, very soon after the removal of the check dams (but not the sediment stored behind the check dams), so that subsequent flushing flows routed and dispersed the stored sediment throughout the downstream reaches of the channel.

The return to clockwise hysteresis suggests that large, concentrated sediment sources were largely eliminated via the dispersal of the check-dam stored sediment and revegetation and soil stabilization of the stream-crossing fills and approach fill slopes. However, the annualized sediment yields during the first post-treatment year after the completion of road construction (Figure 6) show that sediment exports continued to increase as more of the dispersed sediment was flushed from the watershed. Two full years after construction, sediment export exceeded that of the pretreatment period by more than $1000 \mathrm{~kg} / \mathrm{y}$, and was just slightly less than the losses during the construction period. Complete flushing of sediment is not expected for some time, because sediment can be stored in headwater channels for decades, or longer (Madej 1987; Brakebill et al. 2010), and the residual sediment effects often extend well beyond the period of elevated sediment delivery. Long-term storage is possible in part because sediment flushing does not occur consistently through the year across all storms. Instead, it occurs predominantly during only a few major events each year (Edwards \& Owens 1991; Kochenderfer \& Wendel 1980).

\section{Implications}

Given the potential for long-term storage of sediment in streams and the adverse impacts of that sediment on aquatic life and stream stability (Newcombe \& MacDonald 1991; Wood \& Armitage 1997), the need for control of erosion and sedimentation is obvious. The amount of disturbance associated with the construction of stream crossings and approach fill slopes makes these features key considerations during road construction. While forest road studies have made suggestions to improve construction and maintenance techniques (see e.g. Lane \& Sheridan 2002; Luce \& Black 2001), surprisingly few state forestry BMP manuals have practices specifically focused on controlling sediment delivery during construction of stream crossings and fill slopes, especially fill slopes in 


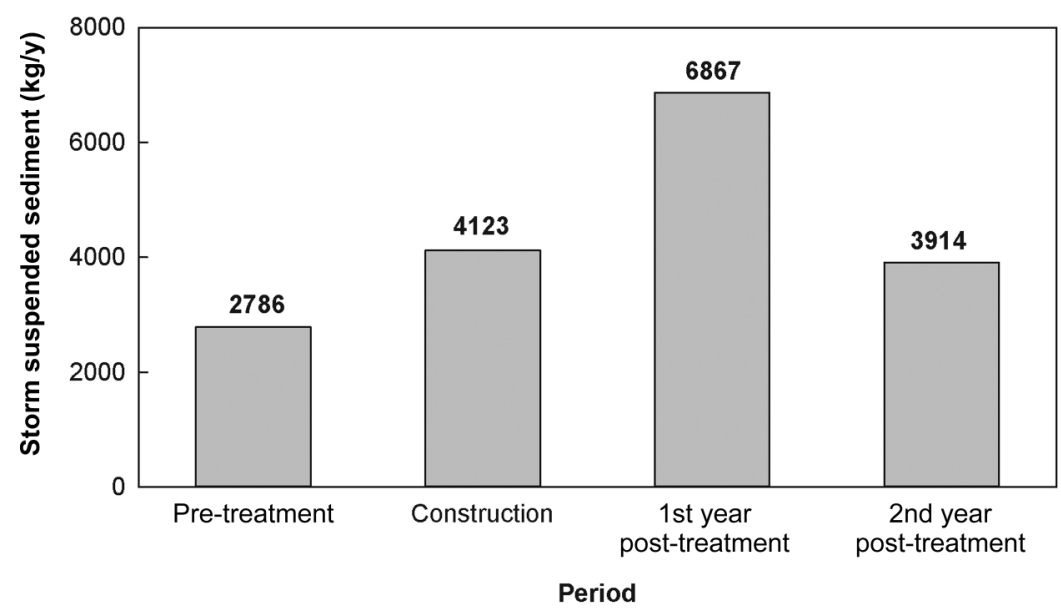

Figure 6. Annualized total suspended sediment for the pre-treatment period, construction period, and each of the first two full years after road construction was completed (pre-treatment $=$ November 1999 to 7 July 2002; construction $=8$ July 2002 to September 2003; 1st year post-treatment = October 2003 to September 2004; 2nd year post-treatment $=$ October 2004 to September 2005).

close proximity to water bodies. In fact, BMPs concerning the actual construction of stream crossings tend to be very general, providing little specific information about controlling sediment delivery when crossings are installed.

The language in West Virginia's BMP manual is representative of the lack of specificity in sedimentcontrol techniques commonly found in most state BMPs for forest operations. The manual addresses the issue of stream crossings primarily with the following BMPs: (1) avoid or minimize stream crossings; (2) install culverts only if a bridge is not available or practical; and (3) cross streams at as close to a right angle as possible (West Virginia Division of Forestry 2009). While these practices can reduce impacts, they may provide only a modicum of protection from sediment delivery in areas where crossings are installed. In the humid East, it is difficult to access forested watersheds without stream crossings due to the density of stream channel networks. Also, because most forest lands in the East are privately owned and bridges tend to be more expensive to purchase and install compared to culverts, stream crossings tend to be dominated by culverts and in some cases by fords.

Substantive changes in sediment delivery from stream crossings are likely to result only from more specific BMP requirements and training, with particular focus on the construction period. Contracts often have clauses that require BMP implementation, such as seeding and mulching, within a given time period (e.g. 30 days) following completion of the activities, but may have little language describing techniques to be employed during crossing construction, when stream sedimentation tends to be greatest. When disturbance activities are prolonged and stretch across wet seasons, the use of interim or temporary BMPs could alleviate many of the sediment-delivery problems that were observed in this case study. Temporary seeding and mulching, especially in crossing and approach areas, and installation of temporary road-drainage structures at a spacing similar to that required for road completion, would improve erosion control and sediment movement, even if road-surfacing materials were present. On this road, only five water-control structures were installed on the entire $0.9-\mathrm{km}$ length over the winter, and seed establishment and mulch were absent in the crossings and on the approach fill slopes during that period (Stedman 2008).

Weaver \& Hagans (1994) recommended full bench construction in all stream-crossing areas to eliminate mechanical sediment delivery during construction and reduce erosion to streams following construction. In full bench construction, the driving surface is constructed entirely on residual soils, and no sidecast material is placed or pushed downslope. Thus, fill slopes are eliminated. Instead, the excavated material that would normally be used to create fill slopes is taken away from the stream-crossing areas and used for road surface fill where needed. Full bench construction is a stream-crossing BMP, but it is not often mentioned in state BMP manuals, and rarely used in the eastern US, due to its higher cost compared to cut-and-fill slopes. The only reference to full bench construction in West Virginia $\mathrm{BMPs}$ is the statement, "To minimize erosion sources, cut and fill slopes within the streamside 
management zone should be minimized in accordance with other safety and design criteria" (West Virginia Division of Forestry 2009).

Stedman (2008) observed that increased approach angles of cut-and-fill roads to the stream, used in conjunction with the standard BMP of having roads cross streams at a 90-degree angle, appears to reduce sediment delivery. This practice shortens the length of road that is near the stream and thereby helps reduce sediment delivery during fill-slope construction as well as water- and gravity-driven erosion following fill-slope construction.

Additional attention to stream-crossing construction is needed on three fronts. First, state BMPs and BMP education must do a better job of recognizing and preventing problems that exist during crossing construction. Often, the sediment delivery that results during construction is ignored and considered an unavoidable consequence of the disturbance. Second, the effectiveness of current practices must be rigorously quantified so that the costs and benefits of different practices can be compared realistically, and stronger emphasis placed on the most effective practices. Protocols and survey methods are available to assess BMP effectiveness and road conditions (Ryder \& Edwards 2006; Mills et al. 2007), but their use is not yet widespread. And third, new techniques must be developed that can control the erosion and sediment delivery resulting from stream-crossing construction. While further research in the area of BMP development may be considered unnecessary by some, it is vital to the improvement of water quality in the future as human demands on these ecosystems increase.

\section{Conclusions}

Even though the majority of daily samples were collected during periods not affected by storm events, there were significant increases from pretreatment to post-treatment (which included a portion of the construction period) in both parameters. In the post-treatment period, 70 daily samples had increases of more than $10 \mathrm{NTU}$ over background turbidity levels, as determined using the pre-treatment sample average as an estimate of background conditions; based on this approach of accounting for background conditions, these samples would have exceeded West Virginia water-quality standards. Most of these samples were collected during construction and soon after construction was completed. Daily SSC concentrations also increased, but the increases were smaller and spread out through much of the post-treatment period, suggesting that turbidity and SSC were influenced by particles of different sizes.

Turbidity and SSC sampled during storms were also higher during post-treatment relative to pretreatment. Turbidity increases again were concentrated primarily around the time of construction, whereas SSC increases were expressed as small changes in concentration but spread over much of the post-treatment period.

Substantial changes in sediment regimes in the watershed were evident from changes in hysteresis that occurred for about seven months of the construction period. Large inputs of sediment from the crossing installation, crossing fills, and fill slopes in the approaches to the crossings provided short-term sources of excessive amounts of sediment to the channel, which resulted in both turbidity-discharge and SSC-discharge relationships temporarily shifting from clockwise hysteresis to counter-clockwise hysteresis. After these sediment sources were stabilized with vegetation, and concentrated sources of sediment behind in-stream check dams were dispersed, hysteresis again became clockwise.

Sediment loads two years after road completion show improving conditions in stream-water quality, but sediment from the crossings is still present in the channel and may require decades to become fully flushed from the watershed. Given the long-term effects that can result, improvements in BMPs specifically associated with stream crossings, especially during construction, are well warranted.

\section{References}

Asselman NEM. 1999. Suspended sediment dynamics in a large basin: the River Rhine. Hydrol Processes. 13 (10):1437-1450.

Bača P. 2002. Temporal variability of suspended sediment availability during rainfall-runoff events in a small agricultural basin. European Network of Experimental Representative Basins (ERB) and Northern European Flow Regimes from International Experimental and Network Data (FRIEND) Project 5 Conference. Bratislava (Slovakia): Institute of Hydrology, Slovak Academy of Sciences.

Bilby RE, Sullivan K, Duncan SH. 1989. The generation and fate of road-surface sediment in forested watersheds in southwestern Washington. For Sci. 35 (2):453-468.

Binkley D, Brown TC. 1993. Forest practices as nonpoint sources of pollution in North America. Water Resour Bull. 29(5):720-729.

Brakebill JW, Ator SW, Schwarz GE. 2010. Sources of suspended-sediment flux in streams of the Chesapeake Bay watershed: a regional application of the SPARROW model. J Am Water Resour Assoc. 46 (4):757-776. 
Cornish PM. 2001. The effects of roading, harvesting, and forest regeneration on stream water turbidity levels in a moist eucalypt forest. For Ecol and Manage. 152 (2001):293-312.

Day TJ. 1976. On the precision of salt dilution gauging. J Hydrology. 31:293-306.

Day TJ. 1977. Field procedures and evaluation of a slug dilution gauging method in mountain streams. J Hydrology. 16:113-133.

Dent EF, Mills KA, Robben J. 2003. Turbidity off of forest roads in Oregon. In: Total Maximum Daily Load (TMDL) Environmental Regulations-II: Proceedings of the Conference of the American Society of Agricultural and Biological Engineers, 8-12 November 2003, Albuquerque, NM; p. 191-197. St. Joseph (MI): American Society of Agricultural Engineers.

Eaglin GS, Hubert WA. 1993. Effects of logging and roads on substrate and trout in streams of the Medicine Bow National Forest, Wyoming. N Am J Fisheries Manage. 13:844-846.

Edwards PJ, Owens MO. 1995. Simple, inexpensive rainfall activation of automatic stream samplers. Stream Technology Transfer Tips No. 2. Fort Collins (CO): USDA Forest Service, Stream Team.

Edwards PJ, Wang J, Stedman JT. 2009. Recommendations for constructing forest stream crossings to control soil losses. In: Proceedings of the AWRA 2009 Summer Specialty Conference [CDROM]. Middleburg (VA): American Water Resources Association.

Edwards PJ, Williard KWJ, Kochenderfer JN. 2004. Sampling considerations for establishment of baseline loadings from forested watersheds for TMDL application. Environ Monit Assess. 98:201-223.

Edwards WM, Owens LB. 1991. Large storm effects on total soil erosion. J Soil Water Conserv. 46(1):75-78.

Fowler WB, Anderson TD, Helvey JD. 1988. Changes in water quality and climate after forest harvest in central Washington state. Res. Pap. PNW-388. Portland (OR): USDA Forest Service, Pacific Northwest Research Station.

Fredriksen RL. 1970. Erosion and sedimentation following road construction and timber harvest on unstable soils in three small western Oregon watersheds. Res. Pap. PNW-104. Portland (OR): USDA Forest Service, Pacific Northwest Forest and Range Experiment Station.

Harr RD, Nichols RA. 1993. Stabilizing forest roads to help restore fish habitats: a northwest Washington example. Fisheries. 18:18-22.

Hornbeck JW, Reinhart KG. 1964. Water quality and soil erosion as affected by logging in steep terrain. J Soil Water Conserv. 19(1):23-27.

Jones JA, Grant GE. 1996. Peak flow responses to clearcutting and roads in small and large basins, western Cascades, Oregon. Water Resour Res. 32(4):959-974.

Kochenderfer JN, Helvey JD, Wendel GW. 1987. Sediment yield as a function of land use in central Appalachian Forests. In: Proceedings of the Sixth Central Hardwood Forest Conference, p. 497-502. Knoxville (KY): University of Tennessee.

Kochenderfer JN, Hornbeck JW. 1999. Contrasting timber harvest operations illustrate the value of BMPs. In: Proceedings of the 12th Central Hardwood Forest
Conference, p. 128-135. Asheville (NC): USDA Forest Service, Southern Research Station.

Kochenderfer JN, Wendel GW. 1980. Costs and environmental impacts of harvesting timber in Appalachia with a truck-mounted crane. Res. Pap. NE-456. Broomall (PA): USDA Forest Service, Northeastern Forest Experiment Station.

Lane PN, Sheridan GJ. 2002. Impact of an unsealed forest road stream crossing: water quality and sediment sources. Hydrol Processes. 16(2002):2599-2612.

Luce CH, Black TA. 2001. Effects of traffic and ditch maintenance on forest road sediment production. In: Proceedings of the Seventh Federal Interagency Sedimentation Conference, Reno NV; p. V67-V74.

MacDonald LH, Coe DBR. 2008. Road sediment production and delivery: processes and management. In: Proceedings of the First World Landslide Forum, International Programme on Landslides and International Strategy for Disaster Reduction; p. 381384. Tokyo: United Nations University.

MacDonald LH, Smart AW, Wissmar RC. 1991. Monitoring guidelines to evaluate the effects of forestry activities on streams in the Pacific Northwest and Alaska. Rep. EPA 910/9-91-001. Seattle (WA): US Environmental Protection Agency, Region 10.

Madej, MA. 1987. Residence times of channel-stored sediment in Redwood Creek, northwestern California. In: Proceedings of Corvallis Symposium: Erosion and Sedimentation in the Pacific Rim, p. 429-438. Publ. No. 165. Washington (DC): International Association of Hydrological Sciences.

Madej MA, Ozaki V. 1996. Channel response to sediment wave propagation and movement, Redwood Creek, California, USA. Earth Surf Processes Landforms. 21:911-927.

Martin D. 2009. Forest road runoff disconnection survey of private timberlands in Washington. Final report prepared for the Washington Forest Protection Association. Seattle (WA): Martin Environmental.

Megahan WF, Kidd WJ. 1972. Effects of logging roads on sediment production rates in the Idaho Batholith. Res. Pap. INT-123. Ogden (UT): USDA Forest Service, Intermountain Forest and Range Experiment Station.

Mills K, Dent L, Cornell J. 2007. Rapid survey of road conditions to determine environmental effects and maintenance needs. Transp Res Rec. 1989(1):89-97.

Newcombe CP, MacDonald DD. 1991. Effects of suspended sediment on aquatic ecosystems. $\mathrm{N}$ Am J Fisheries Manage. 11(1):72-82.

Reid LM, Dunne T. 1984. Sediment production from forest road surfaces. Water Resour Res. 20(11):17531761.

Reinhart KG. 1964. Effect of a commercial clearcutting in West Virginia on overland flow and storm runoff. J Forestry. 62(3):167-171.

Rice RM, Tilley FB, Datzman PA. 1979. A watershed's response to logging and roads: South Fork of Caspar Creek, California, 1967-1976. Res. Pap. PSW-146. Berkeley (CA): USDA Forest Service, Pacific Southwest Forest and Range Experiment Station.

Rice RM, Wallis JR. 1962. How logging operations can affect streamflow. For Ind. 89(11):38-40.

Ryder R, Edwards P. 2006. A regional protocol for evaluating the effectiveness of forestry best management 
practices at controlling erosion and sedimentation. In: Proceedings of the Eighth Federal Interagency Sedimentation Conference [CD-ROM]. Advisory Committee on Water Information, Subcommittee on Sedimentation; SAS/STAT 9.1 user's guide; 2004; Reno, NV. Cary, NC: SAS Institute.

SAS Institute. 2004. SAS/STAT 9.1 user's guide. Cary (NC): SAS Institute.

Stedman JT. 2008. To-stream sediment delivery and associated particle size distributions in unmanaged and managed forested watersheds. MS thesis, Department of Forestry,Southern Illinois University, Carbondale.

Strausberg S. 1983. Turbidity interferes with accuracy in heavy metals concentrations. Ind Wastes. 29(2):16-21.

Stuart GW, Edwards PJ. 2006. Concepts about forests and water. Northern J Appl Forestry. 23(1):11-19.

Swift LW Jr. 1988. Forest access roads: design, maintenance and soil loss. In: Forest Hydrology and Ecology at Coweeta. Ecol Stud. 66:313-324.

Weaver WE, Hagans DK. 1994. Handbook for forest and ranch roads. Prepared for the Mendocino County Resource Conservation District, Ukiah, CA. Available from: http://www.krisweb.com/biblio/gen_mcrcd_weaveretal_1994_handbook.pdf.

Weaver W, Hagans D. 2004. Road upgrading, decommissioning, and maintenance: estimating costs on small and large scales. In: Proceedings of the NMFS Salmonid Habitat Restoration Cost Workshop, p. 80-103. Washington (DC): National Marine Fisheries Service, National Oceanic and Atmospheric Administration, US Department of Commerce.

Wemple BC, Jones JA, Grant GE. 1996. Channel network extension by logging roads in two basins, western Cascades, Oregon. J Am Water Resour Assoc. 32 (6):1195-1207.

West Virginia Divison of Forestry. 2009. West Virginia best management practices for controlling soil erosion and sedimentation from logging operations. Charleston (WV): West Virginia Division of Forestry.

Williams GP. 1989. Sediment concentration versus water discharge during single hydrologic events in rivers. J Hydrology. 111(1989):89-106.

Wood PJ, Armitage PD. 1997. Biological effects of fine sediment in the lotic environment. Environ Manage. 21(2):203-217. 